\title{
AMPLIFIKASI GEN 16S-rRNA BAKTERI EPIFIT PADA ALGA MERAH Kappaphycus alvarezii
}

(16S-rRNA Gene Amplification of Epiphytic Bacteria in Red Algae Kappaphycus Alvarezii)

\section{Rico Taareluan', Letha L. Wantania1, Elvy L. Ginting1, Remy E.P Mangindaan', Deislie R.H Kumampung ${ }^{1}$, Reni L. Kreckhoff ${ }^{2}$, Stenly Wullur ${ }^{1}$.}

1Program Studi Ilmu Kelautan, FPIK Unsrat Manado.

2Program Studi Budidaya PerairanFPIK Unsrat Manado.

*e-mail : stenlywullur@unsrat.ac.id

\begin{abstract}
Bacteria are microscopic organism found living in marine algae. So far, species of bacteria in marine algae are not well known. In this study, epiphytic bacteria in algal species of Kappaphycus alvarezii (red algae) were isolated to amplify their 16S-rRNA gene. Sample K.alvarezii was collected from the island of Nain. The isolated epiphytic bacteria from the red algae K.alvarezii were grown in Nutrient Broth (NB) media. DNA extraction was carried out using InnuPREP DNA Mini Kit. 16SrRNA genes was performed using primer pair of $8 \mathrm{~F}$ and $1492 \mathrm{R}$. Two different character of epiphytic bacteria were successfully isolated from $K$. alvarezii. 16S-rRNA genes from the two isolates was successfully amplified, indicated by the presence of DNA band in each sample gel electrophoreses at around 1500 bp.
\end{abstract}

Keywords : Amplification, 16S-rRNA Genes, Kappapchycus alvarezii, Bacterial, Epiphytic

Bakteri adalah organisme mikroskopis yang ditemukan hidup di alga laut. Sejauh ini, spesies bakteri di alga laut belum dikenal. Dalam penelitian ini, bakteri epifit pada spesies alga Kappaphycus alvarezii (alga merah) diisolasi untuk memperkuat gen 16S-rRNA mereka. Sampel K.alvarezii dikumpulkan dari pulau Nain. Bakteri epifit terisolasi dari alga merah K.alvarezii ditanam dalam media Nutrient Broth (NB). Ekstraksi DNA dilakukan dengan menggunakan InnuPREP DNA Mini Kit. Gen 16S-rRNA dilakukan dengan menggunakan pasangan primer 8F dan 1492R. Dua karakter bakteri epifit yang berbeda berhasil diisolasi dari K. alvarezii. Gen 16S-rRNA dari dua isolat berhasil diamplifikasi, ditunjukkan oleh adanya pita DNA pada setiap sampel gel elektroforesis sekitar $1500 \mathrm{bp}$.

Kata Kunci: Amplifikasi, gen 16S-rRNA, Kappapycus alvarezii, Bakteri, Epifit

\section{PENDAHULUAN}

Alga laut memainkan

peran penting dalam struktur ekosistem

perairan pantai (Jones, dkk
1994). Selain merupakan komponen utama produksi primer, alga laut ini juga merupakan tempat mencari makan dan berlindung bagi banyak spesies invertebrate (Wilson, dkk 1990). Bagian permukaan tubuh alga laut merupakan 
juga habitat bagi berbagai komunitas mikroorganisme. Dilaporkan bahwa komunitas mikroorganisme yang berasosiasi dengan alga memiliki peran unik terhadap pertumbuhan dan kelangsungan hidup alga sebagai inangnya. Komunitas-komunitas mikroorganisme asosiatif pada alga juga dapat mambantu pertumbuhan beberapa jenis alga (Provasoli dan Pinter, 1980, Nakanishi, dkk 1996, Matsuo, dkk 2003, Marshal, dkk 2006) dan berperan penting juga dalam pelepasan dan sentlement spora alga, serta memiliki pengaruh positif terhadap penyediaan nutrisi bagi alga (Joint, dkk 2007). Lebih jauh lagi ditambahkan bahwa mikroorganisme asositif pada alga ini ternyata berperan penting dalam settlement larvae berbagai jenis hewan invertebrate laut lainya (Johnson dan Sutton, 1994).

Sejauh ini, penelitian tentang keberadaan komunitas mikroorganisme asosiatif pada alga masih sangat kurang, padahal keberadaan mikroorganisme asosiatif alga ini, dapat menjadi pijakan kuat dalam menguak berbagai fenomena ekologi terkait alga dan interaksinya dengan berbagai jenis invertebrata serta biota air lainnya dalam satu komunitas. Tak kalah penting juga, pemahaman tentang mikroorganisme asosiatif pada alga ini dapat menjadi acuan dalam memahami penyebaran dan penangan penyakit dalam industri budidaya alga.

\section{METODE PENELITIAN}

Penelitian ini dilaksanakan di Laboratorium Biologi Molekuler dan Farmasitika Laut, Fakultas Perikanan dan Ilmu Kelautan, Universitas Sam Ratulangi Manado. Sampel yang digunakan dalam peneltian ini adalah alga $K$. alvarezii yang diambil dari Pulau Nain, Kecamatan Wori, Kabupaten Minahasa utara.

Kultur bakteri epifit dari alga $K$. alvarezii menggunakan media Nutrient agar (NA). Media NA disiapkan dengan cara menambahkan $1 \%$ NB dan $2 \%$ agar dan disterilisasi pada suhu $121^{\circ} \mathrm{C}$ selama 30 menit. Media tersebut disebarkan dalam cawan petri steril sebanyak kurang lebih $10 \mathrm{ml}$.

Permukaan alga $K$. alvarezii digoreskan di atas permukaan media NA dan selanjutnya diinkubasi pada suhu $37^{\circ} \mathrm{C}$ selama $24-48$ jam. Adanya bakteri yang tumbuh pada media NA ditandai dengan terbentuknya koloni bakteri.

Setiap koloni bakteri yang tumbuh selanjutnya dipisahkan berdasarkan karakteristik morfologi meliputi ukuran, bentuk, warna, dan elevasi. Isolat yang memiliki karakteristik morfologi yang berbeda kemudian digunakan untuk analisis molekuler selanjutnya.

Ekstraksi DNA isolate bakteri epifit alga menggunakan Innuprep DNA mini kit. Setiap isolate bakteri dikultur pada media NB 1 1\% NB dalam $100 \mathrm{ml}$ aquades + air laut steril). Empat $\mathrm{ml}$ kultur bakteri dimasukkan ke dalam tube ependorf, ditambah lysis solution sebanyak $200 \mu \mathrm{l}$ dan proteinase $\mathrm{K} 25 \mu \mathrm{l}$. Sampel dihomogenkan dengan menggunakan vortex selama 5 detik dan diinkubasi selama 3 jam pada suhu $50^{\circ} \mathrm{C}$ dengan menggunakan thermoblock lalu dipindahkan ke dalam prefilter diatas tubereceiver 2,0 ml. Sampel kemudian disentrifugasi dengan kecepatan 12.000 rpm selama 1 menit dan ditambahkan binding solution SBS ke dalam sampel. 
Sampel selanjuytnya dihomogenkan dengan menggunakan pipet, kemudian dimasukkan ke dalam spin filter dan ditempatkan dalam tube receiver $2,0 \mathrm{ml}$ yang baru.

Sampel disentrifugasi kembali pada kecepatan $12.000 \mathrm{rpm}$ selama 2 menit kemudian tube receiver dan cairan hasil filtrasi dibuang. Selanjutnya spin filter di tempatkan ke dalam tube receiver 2,0 ml yang baru. Washing solution HS ditambahkan sebanyak $500 \mu \mathrm{l}$ kedalam spin filter dan disentrifugasi dengan kecepatan 12.000 rpm selama 2 menit. Sampel dipindahkan pada tubereceiver 2,0 ml yang baru, kemudian ditambahkan Washing solution MS sebanyak $750 \mu \mathrm{l}$. Selanjutnya sampel disentrifugasi kembali dengan kecepatan 12.000 rpm selama 2 menit. Kemudian sampel dipindahkan ke tube receiver $2,0 \mathrm{ml}$ yang baru, dan disentrifugasi dengan kecepatan 12.000 rpm selama 1 menit. Tubereceiver dikeluarkan lalu spin filter diletakkan kedalam elution tube $1,5 \mathrm{ml}$ dan ditambahkan elution buffer sebanyak 100 $\mu \mathrm{l}$, kemudian diinkubasi selama 5 menit pada suhu ruangan, selanjutnya di sentrifugasi pada kecepatan $10.000 \mathrm{rpm}$ selama 1 menit.

Teknik elektroforesis gel dilakukan untuk memeriksa keberhasilan isolasi DNA. Pertama, disiapkan gel agarose $1 \%$ sebanyak $30 \mathrm{ml}$ dengan melarutkan $0,3 \mathrm{gr}$ bubuk agarose ke dalam $30 \mathrm{ml}$ 10x TBE buffer dan ditambahkan $27 \mathrm{ml} \mathrm{ddH_{2 }} \mathrm{O}$. Larutan agarose dipanaskan hingga mendidih setelah itu diangkat dan didiamkan selama 10 menit, kemudian ditambahkan 0,6 $\mu$ l cyber green DMSO lalu gel dituangkan ke dalam cetakan gel tray dan dibiarkan hingga mengeras selama \pm 30 menit. Lalu gel agarose dipindahkan ke elektroforesis.

Empat (4) $\mu \mathrm{l}$ hasil ekstraksi DNA diambil dan dicampurkan dengan $1 \mu \mathrm{l} 10 \mathrm{x}$ Loading Buffer di atas parafilm kemudian dimasukan $5 \mu$ campuran ke dalam sumur. Sebanyak $2 \mu \mathrm{l}$ ladder DNA marker 100bp, dimasukkan ke dalam sumur DNA berbeda sebagai penanda berat molekul, selanjutnya dielektroforesis menggunakan 1x TBE buffer pada 80 volts selama 30 menit. Gel selanjutnya dipindahkan ke UVtransilluminator, untuk pengamatan pita hasil ekstraksi.

Amplifikasi DNA bakteri dilakukan menggunakan alat Polymerase Chain Reaction (PCR). Amplifikasi gen 16SrRNA dilakukan dengan menggunakan Primer 8F dan 1492R. Sebelum dilakukan amplifikasi, dibuat campuran $5 \mu \mathrm{l} 5 \mathrm{x}$ Hotfirepool, $17 \mu \mathrm{lddH} 2 \mathrm{O}, 1 \mu \mathrm{l}$ Primer 8F 10x, $1 \mu$ Primer 1492R 10x, dan $1 \mu l$ sampel. Campuran tersebut dimasukkan ke dalam tube Eppendorf khusus untuk PCR dengan total campuran $25 \mu \mathrm{l}$. Setelah campuran dibuat, sampel dirunning di PCR dengan siklus: (1) 95으 selama 6 menit; (2) 95ㅇ selama 30 detik; (3) $52^{\circ} \mathrm{C}$ selama 30 detik; (4) $72^{\circ} \mathrm{C}$ selama 30 detik; (5) $72^{\circ} \mathrm{C}$ selama 10 menit. Siklus PCR dilakukan sebanyak 35 siklus.

\section{HASIL DAN PEMBAHASAN}

Bakteri epifit pada alga merah K.alvarezii berhasil ditumbuhkan pada media NA (Gambar 1). 


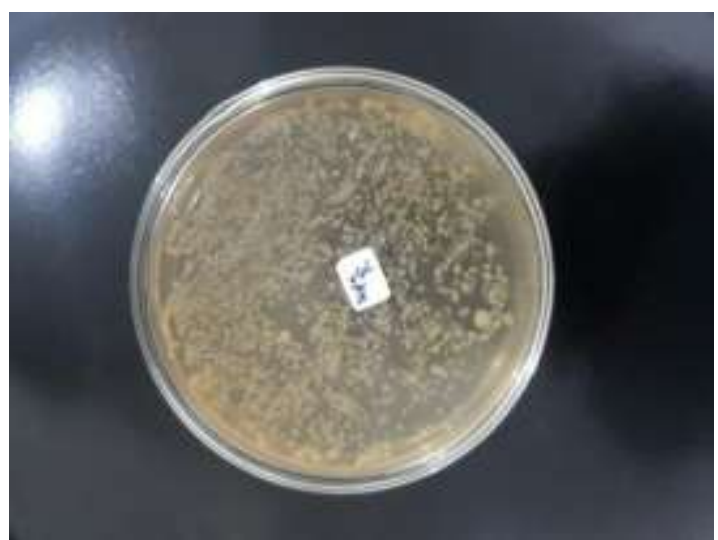

Gambar 1. Bakteri epifit yang tumbuh dalam media Nutrient Agar.

Berdasarkan hasil pengamatan karakteristik morfologi, diperoleh 2 isolat bakteri epifit pada alga merah $K$. alvarezii (Gambar 2). Morfologi isolat bakteri epifit pada alga merah $K$. alvarezii dapat dilihat pada Table 1.

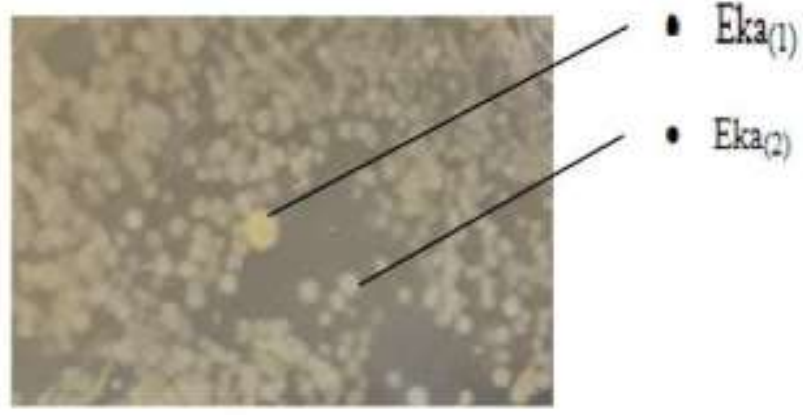

Gambar 2. Isolat Bakteri Epifit pada Alga K. alvarezii.

Tabel 1. Karakteristik Isolat Bakteri Epifit pada Alga Merah K. alvarezii.

\begin{tabular}{|l|l|l|l|l|}
\hline \multirow{2}{*}{ Kode Isolat } & \multicolumn{4}{|c|}{ Karakteristik Koloni } \\
\cline { 2 - 5 } & Bentuk & Warna & Tepian & Elevasi \\
\hline $\mathrm{Eka}_{(1)}$ & Circular & Kuning & Convex & Raised \\
\hline $\mathrm{Eka}_{(2)}$ & Circular & Putih & Entire & Raised \\
\hline
\end{tabular}

Berdasarkan (Table 1), isolate $\mathrm{Eka}_{(1)}$, dan $\mathrm{Eka}_{(2)}$ memiliki koloni yang berbentuk circular (memiliki tepian yang teratur/rata). Isolate bakteri

Eka(1) memiliki warna kuning sedangkan isolate bakteri $\mathrm{Eka}(2)$ berwarna putih.

DNA dari kedua isolate bakteri ini berhasil diisolasi. Visualisasi sampel DNA isolate bakteri epifit pada alga k.alvarezii didapatkan adanya pita DNA pada lintasan sampel Eka(1) dan Eka(2) yang terletak pada daerah dekat dengan masing-masing sumur sampel pada gel elektroforesis. Pita DNA yang muncul tersebut mengindikasikan keberhasilan ektraksi DNA bakteri epifit pada k.alvarezii sehingga dapat digunakan untuk tahap analisis molekuler selanjutnya.

Hasil ektraksi DNA K. alvarezii kemudian digunakan sebagai DNA template dalam proses amplifikasi gen 
16S-rRNA dengan menggunakan kombinasi pasangan primer $8 \mathrm{f}$ dan primer 1492. Primer mempunyai fungsi untuk mengenali dan menandai fragmen sampel DNA (template) yang akan di amplifikasi (Peloa dkk, 2015)

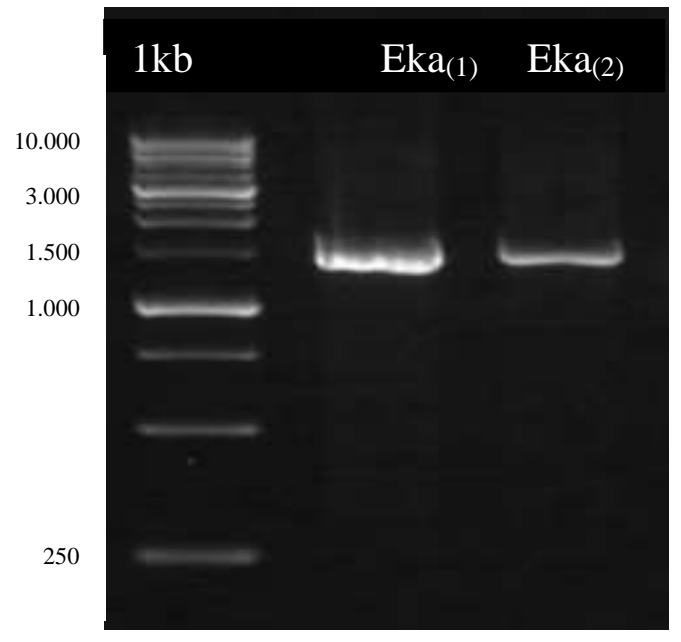

Gambar 3. Visualisasi gel elektroforesis hasil Amplifikasi Gen 16S-rRNA isolat bakteri epifit pada alga merah $K$. alvarezii

Berdasarkan hasil visualisasi gel elektroforesis dapat dilihat bahwa masing-masing lintasan gel pada sampel $\mathrm{Eka}_{(1)}$, dan Eka ${ }_{(2)}$ terdeteksi adanya pita DNA. Munculnya pita DNA pada masingmasing lintasan gel sampel menunjukan keberhasilan amplifikasi gen 16S-rRNA dari masing-masing isolate alga dalam penelitian ini. Tampakan pita DNA yang muncul pada masing-masing lintasan gel terlihat jelas pada posisi sekitar 1500 bp, mengindikasikan keberhasil amplifikasi gen target.

\section{KESIMPULAN}

Sebanyak dua isolate bakteri epifit alga merah $K$. alvarezii berhasil diisolasi $\left(E_{k a}(1)\right.$ dan $\left.E_{k a}(2)\right)$ Gen 16S-rRNA kedua isolate bakteri tersebut berhasil diamplifikasi menggunakan primer 8F dan 1492R yang ditandai dengan adanya pita DNA pada posisi sekitar $1500 \mathrm{bp}$.

\section{DAFTAR PUSTAKA}

Aprilia, F. E., Soewondo A., Widodo., dan Toba A.H A. 2014. Amplifikasi Gen COI dan 16s rRNA dari vertebrate Laut Plakobranchus ocellatus, Jurnal Biotropika, 2(5), hal 276-278

Cappucino, J.G., and Sherman N. 1998. Microbiology, A Laboratory Manual. Benjamin/Cummings Science Publishing, California.

Joint I, Tait K, Wheeler G. (2007). Crosskingdom signalling: exploitation of bacterial quorum sensing molecules by the green seaweed Ulva. Philos Trans Roy Soc B 362: 1223-1233.

Jones CG, Lawton JH, Shachak M. (1994). Organisms as ecosystem engineers. Oikos 69: 373-386.

Johnson CR, Sutton DC. (1994). Bacteria on the surface of crustose coralline algae induce metamorphosis of the crown-of-thorns starfish Acanthaster planci. Mar Biol 120: 305-310.

Mopay, M., S. Wullur, dan E. Kaligis. 2017. Identifikasi Molekuler Sirip Ikan Hiu yang Didapat Dari Pengepul Sirip Di Minahasa. Jurnal Pesisir dan Laut Tropis Vol.1(2): Hal. 1-7.

Nakanishi K, Nishijima M, Nishimura $M$, Kuwano K, Saga N. (1996). Bacteria that induce morphogenesis in Ulva pertusa 
(Chlorophyta) grown under axenic conditions. J Phycol 32: 479-482.

Peloa, A. Wullur, S. Sinjal, C.A. 2015. Amplifikasi Fen Cytochrome Oxidase Subunit I Dar Sampel Sirip Ikan Hiu Dengan Menggunakan Beberapa Pasangan. Primer.Jurnal Pesisir dan Laut Tropis. 1(1):37-42.

Provasoli L, Pintner IJ. (1980). Bacteria induced polymorphism in an axenic laboratory strain of Ulva lactuca (Chlorophyceae). J Phycol 16: 196-201.

Wantania, L. L., E. L. Ginting., S. Wullur. 2016. Isolasi Bakteri Simbion Dengan Spons dari Perairan Tongkeina Sulawesi Utara. Jurnal LPPM Bidang Sains dan teknologi. 3(1): 57-65.

Willey, J. M., Sherwood L.M., and Woolverton C, J.2008. Prescoot, Harley, andKlein Microbiology seventh Edition. The McGraw-hill Companies, Inc. New York, Hal 101-149

Wilson KA, Able KW, Heck KL. (1990). Predation rates on juvenile blue crabs in estuarine nursery habitats- evidence for the importance of macroalgae (Ulva lactuca). Mar Ecol Progr Ser 58: 243-251. 